\title{
The Programme of Clinical Experience and Evaluation Employed at the University of Cape Town
}

\section{iM. J. FUTTER}

\section{SUMMARY}

This paper provides a brief description of the system of clinical evaluation used at the University of Cape Town. It gives the objectives of the clinical programme and the method of clinical supervision employed to achieve them. Some general problems of evaluation are discussed.

\subsection{INTRODUCTION}

In order to fulfil the requirements for the degree of B.Sc. Physiotherapy and ensure that the public is protected, students have to be assessed accurately in the clinical situation so that their level of competence can be tested.'

\subsection{OBJECTIVES OF THE CLINICAL PROGRAMME}

At the end of the clinical programme the student is

M. J. Futter, B.A., Dip. (Phys), D.S.E., Assistant Lecturer, Dept. of Physiotherapy, University of Cape Town

\section{OPSOMMING}

Hierdie referaat gee ' $n$ kort beskrywing van die kliniese evaluasie stelsel wat by die Universiteit van Kaapstad gebruik word. Die doelwitte van die kliniese program en die metode van kliniese toesig wat gebruik word om hulle te bereik, word uiteengesit. Sommige algemene probleme van evaluasie word bespreek.

expected to have the knowledge, technical skills, and attitudes to:

2.I Integrate and apply theoretical knowledge intelligently in the clinical situation.

2.2 Extract the relevant facts from the patient's medical records and interpret pertinent special investigations accurately.

2.3 Evaluate a patient comprehensively.

2.4 Plan and progress an appropriate treatment programme.

2.5 Perform an effective and safe treatment according to his/her level of study.

2.6 Keep adequate documentation of the treatments.

2.7 Recognise complications associated with the patient's condition and avoid dangerous practice. 


\section{AKRON Therapy products from Medical Distributors (Pty) Ltd}

\section{AKRON ISOKINETIC ISOTONIC THERAPY EQUIPMENT}

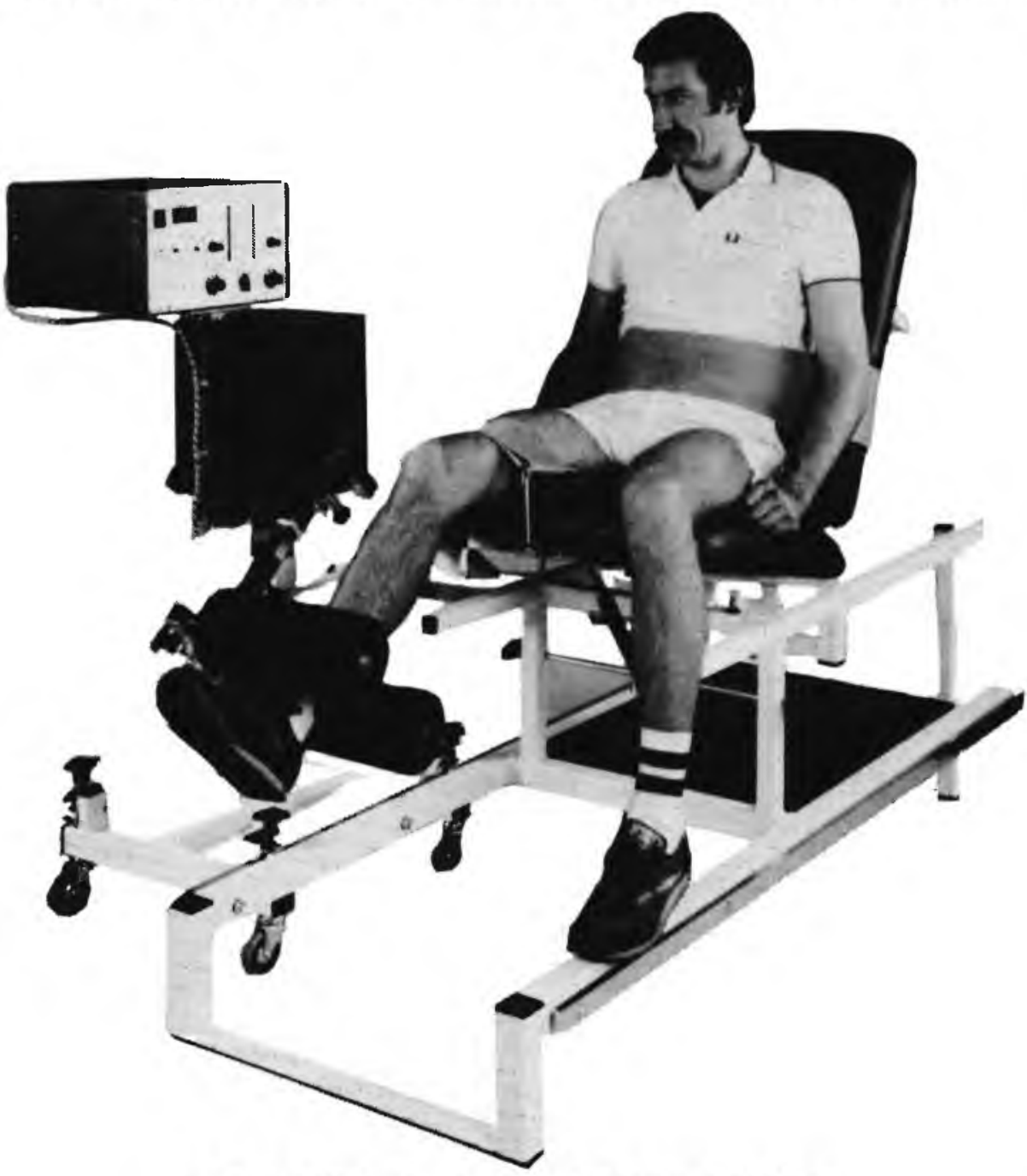

FOR UPPER AND LOWER LIMBS

FOR PARTICULARS WRITE TO THE SOLE DISTRIBUTORS:

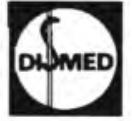

\section{MEDICAL DISTRIBUTORS ${ }_{\text {EOMS BPK }}^{\text {PTY }}$}

\begin{tabular}{llll}
\hline PO Box 3378 & Johannesburg & 2000 & Phone : 29-0611 \\
\hline PO Box 195 & Cape Town & 8000 & Phone : 47-4440 \\
\hline PO Box 5298 & Durban & 4000 & Phone : $37-1501$ \\
\hline
\end{tabular}


2.8 Treat patients as individuals, understanding the influence of social, economic and psychological factors which may affect the patient's condition and subsequent progress in treatment.

2.9 Communicate effectively with the patient, other members of the medical team and colleagues, understanding the importance of working within the medical team.

2.10 Behave in a professional manner at all times in the clinical situation.

2.II Be aware of ethical factors involving the patient and the medical team.

2.12 Know his/her own limitations and further his/her knowledge by additional independent study to maximise the effectiveness of patient treatment.

\subsection{THE PROGRAMME OF CLINICAL SUPERVISION EMPLOYED TO PROMOTE THE OBJECTIVES}

) The purpose of clinical supervision is to help the students acquire and integrate knowledge and use their judgement in situations which cannot be achieved by means of lectures. It is the major clinical tool ${ }^{2}$ to assist them in using the knowledge they have, to understand, analyse and evaluate clinical conditions whilst developing qualities of observation and decision making. By having close contact with reality they are able to make comparisons between theory and practice and can develop self-confidence in their decision-taking.

The students are also prepared for examination expectations. By experiencing clinical supervisors observing their treatments they are placed in situations similar to those of the examinations and are therefore less likely to suffer from negative levels of anxiety in the actual examination situations. ${ }^{3}$

At the beginning of their clinical experience students are provided with a guide to the experience they will receive in each clinical area. This guide was drawn up by the clinical physiotherapists at Groote Schuur Hospital and placed into appropriate levels of study by the lecturing staff. It contains information about the theory the students are required to know, the conditions They are likely to see, the treatments they should be able to perform and any administrative duties that need to be carried out in each area.

Students first come into contact with patients in the clinical situation from the second quarter of the second year of study. They spend $4 \frac{1}{2}$ hours per week in the clinical area, each clinical block consisting of four weeks with three or four students in each group.

The main objectives of second year clinical experience is to introduce the students to, and familiarise them with the clinical situation. Supervision consists largely of demonstrations of treatments. They are shown how to extract relevant facts from the patients' medical records and how to evaluate specific conditions affecting, for example, the chest or knee. Assistance is given in planning and documenting treatment programmes. The clinical supervisor acts as a role model for professional behaviour and communicating with the patient and other members of the medical team. The students perform only very basic skills like massage, tapôtement, teaching bed mobility exercises and the supervisor completes the treatments.

Third year students spend $21 / 2$ hours per afternoon in neurology, orthopaedics, outpatients, surgery, medicine, sports injury clinic and the physiotherapy gymnasium.

At this stage the objective of clinical experience is for the student to integrate and apply theoretical knowledge in the clinical situation, to evaluate a patient comprehensively and to plan and progress an appropriate treatment programme. They should communicate effectively with patients and perform effective and safe treatments in a professional manner.

In order to achieve these objectives the students are given 2 periods of clinical supervision per week on a one-to-one basis for 30 - 45 minutes. In most of the clinical areas each student has two different clinical supervisors, one being the lecturer responsible for the lectures of the particular area and the other a clinical supervisor. In addition to this a great deal of time is devoted to the students by the clinical physiotherapists responsible for the patients in the various areas.

Fourth year students spend 4 hours each morning in neurology, burns, hands, cardiothoracic, respiratory intensive care, sports injury clinic, physiotherapy outpatients and cerebral palsy. They also spend one block doing an elective at any recognised hospital in a clinical area of their choice.

During the twice-weekly clinical supervision periods the objectives are as listed in 2.0. The students are expected to see the patient as an individual and to understand the necessity of adapting treatments to the changing circumstances or problems. They are assisted with problem-solving skills and are expected to perform treatments independently with safety, effectiveness and proficiency.

As clinical work is a very effective learning experience ${ }^{4}$ feedback to the student is most important. Continued evaluation, for example, takes place verbally during clinical supervision which allows errors in performance to be pointed out immediately. ${ }^{5}$

The system of acquiring clinical skills is very much one of dynamic interaction between the clinical supervisor and the student. ${ }^{4}$ For this reason students are encouraged to complete forms (see Fig. 1) in order to evaluate each clinical area stating what they found beneficial, what problems they encountered and any suggestions they may have to improve on the experience gained in the particular clinical area.

\subsection{THE CLINICAL EXAMINATION}

According to Guilbert ${ }^{4}$ it is the system of clinical evaluation that establishes the degree to which the objectives of the clinical programme have been achieved.

\section{1 End-of-block examinations}

At the end of each clinical block two examiners observe the student treating a patient he/she has not seen previously, for 30-45 minutes. They award a mark on the basis of the treatment performed by 
EVALUATION OF CLINICAL BLOCK

NAME YEAR .FROM..... TO.....

WHAT HAS BEEN HELPFUL ON IHIS BLOCK ?

WHAT PROELEMS DID YOU ENCOUNTER ON THIS BLOCK ?

CAN YOU SUGGEST CHANGES THAT WILL MAKE THIS BLOCK MORE HELPFUL ?

Fig. l. Students feedback form.

the student at the time of the examination. This mark is independent of the general, assessed performance of the student on the block.

The examination consists of four sections (see Figures $1 \mathrm{l}$ and III); assessment, planning, execution and interpersonal relationships. Students have to obtain at least $50 \%$ in each section in order to pass. If the subminimum is not achieved the student fails the entire examination and is awarded a total of $45 \%$.

At the end of the fourth year the students have an additional clinical examination. They assess, plan a treatment programme and treat a patient from a clinical area that has been selected at random an hour before the examination takes place.

\subsection{Clinical evaluations}

The evaluation of the clinical work is given by the clinical physiotherapists who have been responsible for the student during the block. It is an evaluation of the most typical performance of the student over the four weeks. The guide to clinical experience allows the staff to expect certain levels of performance from the student and enables them to judge the student's level of performance accordingly.

The assessment consists of 20 items (see Figures IV and V) marked on a 5-point scale ranging from very good $(90 \%)$ to very poor $(20 \%)$. Provision is

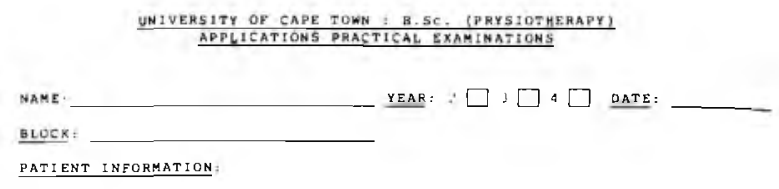

it is suggested that each ated be asrked oett of 23 points. Pleage place yout score for wach drod th the errele provided and the tota

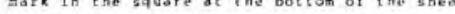

pleasp use the reverse stape tor your comments and working sthet

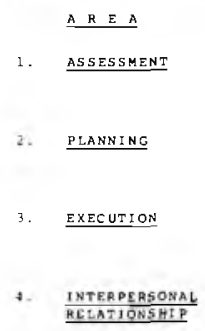

GENERAL COMMENTS:
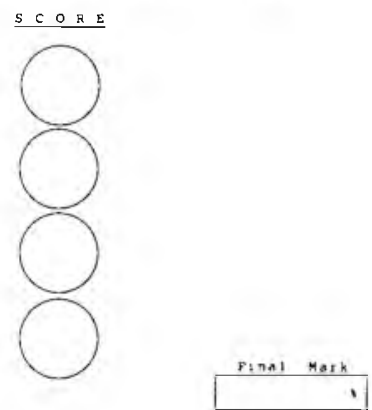

Fig. 2. End-of-block examination form.

PLEASE PUT YOUR COMMENTS FOR EACH AREA ON THIS SIDE AND TRANSFER ANY SCORES TO THE FRONT SIDE

$$
\underline{\text { A R E A }}
$$

\section{ASSESSMENT}

Evaluating patient Comments

2. PLANNING

$\begin{array}{ll}\text { Choosing treatment } & \text { Objectives } \\ \text { procedures } & \text { Proorities }\end{array}$

3. EXECUTION

$\begin{array}{ll}\text { Performing treatment } & \text { Effective } \\ \text { procedures } & \text { Efficient } \\ & \text { Safe } \\ \text { Comfort }\end{array}$

4. INTERPERSONAL RELATIONSHIP

$\begin{array}{ll}\text { Working with patient } & \text { Rapport } \\ & \text { Education } \\ \text { Cax: Capacity } & \end{array}$

Fig. 3. Reverse side of end-of-block examination form. 
made to allow evaluators to omit items that they feel unqualified to judge. After each section, i.e. performance of treatments, application to work, attitude to patients, attitudes to colleagues and professional behaviour, there is provision made for comments by the clinical physiotherapist.
Sternberg6 warns that if these evaluations are not true reflections of performance, the students will not have an accurate idea of their level of ability. Brockway ${ }^{6}$ maintains that their motivation, confidence and desire for further feedback will be affected by this.

\section{UNIVERSITY OF CAPE TOWN}

\section{DEPARTMENT OF PHYSIOTHERAPY}

\section{ASSESSMENT OF STUDENT'S CLINICAL WORK}

Student's Name

Year of Study (place $X$ in square)
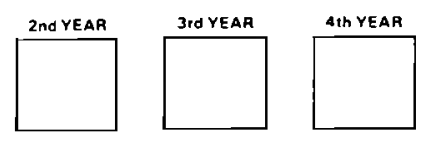

Period worked: From ........ To ..........

Place worked

Clinical Staff in Charge

\section{Notes on Completing this Form}

1. The results of this assessment count towards the student year end marks, so care and consideration in completing this form would be appreciated. A definite number of marks will be awarded for each grade of performance.

2. Do not be afraid to give a high or low mark where it is deserved. You have a responsibılity to discuss with your students their shortcomings. It is WRONG and UNFAIR to let students drifi on in the mistaken belief that they are giving satisfaction.

\section{Performance of Treatments.}

\begin{tabular}{|c|c|c|c|c|c|c|}
\hline & $\stackrel{A}{\text { Verv Good }}$ & Good & $\underset{\text { Satisfactory }}{\mathrm{C}}$ & $\stackrel{D}{D}$ & $\begin{array}{c}\text { E } \\
\text { Verv Poor }\end{array}$ & \\
\hline $\begin{array}{l}\text { 1. Always applies theoretical know- } \\
\text { ledge intelligently. }\end{array}$ & & & & & & $\begin{array}{l}\text { Generally fails to apply theory intelli- } \\
\text { gently. }\end{array}$ \\
\hline 2. Carries out practical techniques well. & & & & & & Practical techniques poorly carried out. \\
\hline 3. Work is done with attention to detail. & & & & & & Insufficient care given to detail. \\
\hline 4. Performs treatments safely. & & & & & & Does not perform treatments safely. \\
\hline $\begin{array}{l}\text { 5. Is responsible i.e Can be relied upon } \\
\text { to carry out instructions. }\end{array}$ & & & & & & Unreliable unless closely supervised. \\
\hline $\begin{array}{l}\text { 5. Is observant of the patient in all re- } \\
\text { spects. }\end{array}$ & . & & & & & Unobservant of patient in all respects. \\
\hline 7. Reports relevant findings. & & & & & & Omits to report relevant information. \\
\hline 8. Keeps good, accurate records. & & & & & & Record keeping poor. \\
\hline $\begin{array}{l}\text { 9. In summary: Carries out treatments } \\
\text { well for a student at this stage of } \\
\text { training. }\end{array}$ & & & & & & $\begin{array}{l}\text { Performs treatments poorly for a student } \\
\text { at this stage of training. }\end{array}$ \\
\hline
\end{tabular}

Comments:- 
If. Application to Work

\begin{tabular}{|c|c|c|c|c|c|c|}
\hline & Very Good & Good & $\begin{array}{c}c \\
\text { Salisfoctory }\end{array}$ & $\begin{array}{c}0 \\
\text { Poor }\end{array}$ & $\underset{\text { Very Poor }}{E}$ & \\
\hline 10. A keen and willing worker. & & & & & & Halt-hearted and indifferent. \\
\hline $\begin{array}{l}\text { 11. Eager to extend theoretical know- } \\
\text { ledge. }\end{array}$ & & & & & & $\begin{array}{l}\text { Appears to lack interest in extending } \\
\text { theoretical knowledge. }\end{array}$ \\
\hline 12. Eager to improve practical skill. & & & & & & $\begin{array}{l}\text { Appears to lack interest in improving } \\
\text { practical skill. }\end{array}$ \\
\hline $\begin{array}{l}13 \text { Shows quickness in grasping the } \\
\text { importance of eseentials. }\end{array}$ & & & & & & $\begin{array}{l}\text { Often fails to grasp the importance of } \\
\text { essentials. }\end{array}$ \\
\hline 14. Work is done promptly. & & & & & & Often slow and tends to hold up work. \\
\hline
\end{tabular}

Commente:-

III. Attitude to Patients

\begin{tabular}{|c|c|c|c|c|c|c|}
\hline & Very Good & Good & $\underset{\text { Satistactory }}{\mathrm{C}}$ & $\begin{array}{l}0 \\
\text { Poor }\end{array}$ & $\begin{array}{c}E \\
\text { Very Poor }\end{array}$ & \\
\hline $\begin{array}{l}\text { 15. Treats patients as individuals, not } \\
\text { "cases". }\end{array}$ & & & & & & Does not treat patients as individuals. \\
\hline $\begin{array}{l}\text { 16. Shows some ability in gaining co- } \\
\text { operation of patients. }\end{array}$ & & & & & & $\begin{array}{l}\text { As yet. lacks ability to gain co-operation } \\
\text { of patients. }\end{array}$ \\
\hline
\end{tabular}

Commente:-

IV. Attitude to Colleagues

\begin{tabular}{|c|c|c|c|c|c|c|c|}
\hline & & $\stackrel{{ }^{A}}{\text { Verv Good }}$ & $\stackrel{8}{\text { Good }}$ & $\underset{\text { Satistactory }}{C}$ & $\begin{array}{c}D \\
\text { Poor }\end{array}$ & $\stackrel{E}{\text { Verv Poor }}$ & \\
\hline 17. & $\begin{array}{l}\text { Co-operative and considerate in deal- } \\
\text { inge with other members of staff } \\
\text { ond colleagues. }\end{array}$ & & & & & & $\begin{array}{l}\text { Unco-operative and inconsiderate in } \\
\text { dealings with other members of staff } \\
\text { and colleagues. }\end{array}$ \\
\hline & $\begin{array}{l}\text { Responds readily to guidance and in- } \\
\text { struction. }\end{array}$ & & & & & & $\begin{array}{l}\text { Appears reluctant to accept advice or in- } \\
\text { struction. }\end{array}$ \\
\hline
\end{tabular}

Commente:-

V. Protesaional Behaviour

\begin{tabular}{|c|c|c|c|c|c|c|}
\hline & Very ${ }^{A}$ Good & $\begin{array}{c}8 \\
\text { Good }\end{array}$ & $\underset{\text { Satistactory }}{C}$ & $\begin{array}{c}D \\
\text { Poor }\end{array}$ & $\begin{array}{c}E \\
\text { Very Poor }\end{array}$ & * \\
\hline $\begin{array}{l}\text { 19. Takes care to eppear neat and well- } \\
\text { groomed. }\end{array}$ & & & & & & Careless of appearance. \\
\hline 20. Unrutfled in all circumsiances & & & & & & Easily "upset" \\
\hline
\end{tabular}

Comments

\section{Subjective evaluation in Percentage}

TOTAL MARK : 


\subsection{Allocation of marks}

Clinical work for the year is regarded as being satisfactory if the student achieves the following:

II Year - passes 4 of 5 clinical blocks

III Year - passes 5 of 7 clinical blocks

IV Year - passes 4 of 6 clinical blocks.

The marks over the year in the monthly block examinations and clinical evaluations contribute $50 \%$ towards Physiotherapy Application IB, IIB and IIIB. The examinations done in the final block of the year contribute the remaining $50 \%$.

This system of examination has been in operation for I year and is at present undergoing evaluation. Results so far indicate that it is effective in identifying problem areas that any student may have and there is a strong positive correlation between results and those of the OSPE's (Objective Structured Practical Examination) used to test technical skills for Physiotherapy Technique IIB and IIIB in second and third year.

\subsection{PROBLEMS ASSOCIATED WITH THE CLINICAL EXAMINATION SYSTEM}

5.1 The extreme complexity of the skills ${ }^{7}$ to be evaluated in the clinical examination situation makes standardisation very difficult.

5.1.1 There is a great deal of variability in the conditions of in- and out-patients as well as in the observers' judgements of the students' performances.

5.1.2 The examination and clinical evaluation forms are standardised and the students' performances in various settings have to be translated to fit the generalised format.

5.1.3 Different examiners are used, even in the same clinical area.

5.1.4 There is variation in the examiners' interpretation of the levels of competence that students from the different years should achieve. ${ }^{8}$

5.2 There is a large degree of subjectivity involved in both end-of-block examinations and clinical evaluations. For this reason examiners are often loathe to evaluate students directly.'

5.3 The relatively quick turnover of clinical staff makes orientation of the clinical evaluation system difficult.

5.4 Ebel $^{8}$ states that time allocated for examinations is frequently insufficient to assess the complex competencies comprehensively.

5.5 Monthly examinations and evaluations are complicated to administer, time-consuming and involve a large number of staff, but as Guilbert ${ }^{4}$ argues, unless evaluations are continuous they have a negative effect and only function to penalise students and do not serve as a learning experience.

5.6 The examination format of two examiners observing a treatment is often distressing for the patient and may also affect the student's level of performance. ${ }^{4}$

5.7 Test anxiety. Sarason ${ }^{3}$ maintains that it is not a major consideration in allocating marks to a student in an examination situation.

\subsection{CONCLUSION}

In view of the complex nature of the factors that have to be examined it is very difficult to make the process of clinical evaluation fully objective.' Although there is a large degree of subjectivity involved in both end-of-block examinations and clinical evaluations, it is the only means of assessing clinical competence in the wide range of clinical situations ${ }^{7}$ and it does allow the examiners the freedom of examining the students knowledge in great depth where necessary. ${ }^{8}$

Quantification of evaluation and planning is possible, but definite criteria and descriptions of terms to be measured have to be indicated in execution and interpersonal relationships in order to minimise the subjectivity. ${ }^{8}$ Ebel $^{8}$ reports that objectivity and reliability are improved by having two competent and experienced examiners who have a thorough knowledge of the field in which they are examining. Further, various forms of assessment by several different individuals is much more likely to be accurate than assessments made by one person. ${ }^{8}$

Guilbert ${ }^{4}$ states that frequent testing, albeit timeconsuming has the advantage of providing a more reliable basis for evaluation and of keeping the lecturer and student aware of the progress that has been made. It is also an opportunity for valuable learning experience where feedback ${ }^{4}$ is given immediately after the examination. Ebel ${ }^{8}$ observes that the examination and awarding of marks tends to stimulate, direct and reward the efforts of the student.

\section{References}

I. Loomis J. Evaluating clinical competence of physical therapy students. Physiotherapy Canada 1985; 37: 83-98.

2. Scully $R$ and Shepherd KF. Clinical Teaching in Physical Therapy Education. Phys Ther 1983; 63: 354.

3. Sarason IG. Empirical Findings and Theoretical Problems in the use of Anxiety Scales. Psychological Bulletin 1960: 403-415.

4. Guilbert JJ. Education Handbook of Health Personnel. World Health Organisation, 1977: 303-345.

5. Wilson M. Supervision: New Patterns and Processes. New York, NY: Associated Press, 1969: 19.

6. Sternberg J, Brockway B. Evaluation of Clinical Skills: an asset oriented approach. J Fam Pract 1979; 8: 1243-1245.

7. Morgan $M$ and Irby D (Eds). Evaluating Clinical Competence in the Health Professions. St Louis: CV Mosby, 1978.

8. Ebel RL. Essentials of Educational Measurement. New Jersey: Prentice-Hlall, 1979: 263-271. 